\title{
URARIA PICTA (JACQ.): A REVIEW ON ETHNOMEDICAL USES, PHYTOCHEMISTRY, AND BIOLOGICAL ACTIVITIES
}

\author{
JAYKUMAR MANE*, DHEERAJ NAGORE, SOHAN CHITLANGE
}

Department of Pharmaceutical Chemistry, Dr. D. Y. Patil Institute of Pharmaceutical Sciences and Research, Pune, Maharashtra, India. Email: jaykumar.mane@gmail.com

Received: 26 November 2020, Revised and Accepted: 16 January 2021

\begin{abstract}
The aim of this systematic review is to provide an in-depth study of ethnological uses, phyto-chemistry, pharmacological activities, and toxicological research in Uraria picta (Jacq.), to identify remaining gaps, and to provide a basis for future research. By searching for the words "U. picta" and "Prishnaparni" in electronic databases such as SciFinder, Web of Science, PubMed, and Google Scholar, information on common uses, phytochemistry, and pharmacological activities was systematically collected. Phytochemical analysis of $U$. picta shows various components such as alkaloids, flavonoids, steroids, terpenoids, phenols, and saponins. The extracts and their isolated components showed numerous in vitro and in vivo pharmacological effects, including urinary tract diseases, tumors, edema, smoking, and dyspnea. On the other hand, searches of patent databases found almost seven applications, highlighting the differences between a large number of published scientific articles and non-existent patent applications. This event demonstrates the technological potential of undiscovered species. Ethnographic research shows that U. picta, an important Asian medicinal plant, is used to treat many diseases. In this review, the ethnobotanical, phytochemical, pharmacological, and ethnological properties of various morphological parts of the $U$. picta plant are highlighted. Future research has provided information for commercial research and has shown that this herb has tremendous potential for pharmaceutical and nutritional applications.
\end{abstract}

Keywords: Uraria picta, Prishnaparni, Ethnobotanical, Phytochemistry, Pharmacological properties.

(C) 2021 The Authors. Published by Innovare Academic Sciences Pvt Ltd. This is an open access article under the CC BY license (http://creativecommons.org/ licenses/by/4.0/) DOI: http://dx.doi.org/10.22159/ajpcr.2021v14i3.40383. Journal homepage: https://innovareacademics.in/journals/index.php/ajpcr

\section{INTRODUCTION}

Uraria picta (Syn. Doodia picta Roxb, Hedysarum pictum Jacq., FamilyLeguminosae: Papilionoidae.) is commonly called "Wizardry" or "Slight-of-hand" and the Prishnaparni or Pithvan plant. It is also found throughout India and almost all places in Bangladesh, Sri Lanka, tropical Africa, the Malaysian Islands, the Philippines, Australia, Africa, and Asia [1-6]. Especially in some diseases of traditional medicine, it is a very important plant, compared to many other plants, in terms of its usefulness and effectiveness. The suffruticose plant is vertical or fertile, $1.5 \mathrm{~m}$ high and is often found in dry grasslands, bare lands and forests. It is one of the key ingredients of "Dashmoolarista," the main Ayurvedic medicine in the Indian medical system, made from the roots of 10 medicinal plants and used for treating general fatigue, mouth ulcers and various gynecological diseases. The formulation Dashmula contains ten roots of medicinal plants: Gambhari (Gmelina arborea), Bilva (Aegle marmelos), Agnimantha (Premna integrifolia), Shoynaka (Oroxylum indicum), Patla (Sterospermum suaveolens), Shalaparni (Desmodium gangeticum), Kantkari (Solanum xanthocarpum), Gokshura (Tribulus terrestris), and Brahati (Solanum indicum) $[3,4,7,8]$. Dashmool is also used as an essential ingredient in the manufacture of more than 109 drug formulations [9,10]. It is also used in other Ayurvedic formulations such as Abana, Amritarishta, Angamardana prashamana kashaya churna, Dashamoola carving, Vyaghri carving, Madhyama Narayana carving, Dashmularishta, and Shira Shuladi vajra Ras $[11,12]$.

Almost all parts of $U$. picta have therapeutic value and are used in the medical system of India to treat fatigue, oral ulcers, and various gynecological diseases [8,13-15]. Echis carinatus is also known as an antiseptic to cure snake [3] and fractures [16]. It contains antiseptic [17], antimicrobial [18], acaricide [19], antiulcerogenic [20], antihypodynamic [21], and antipulmonary hypertension [22] and partial vasodilation [8,9]. In addition to its use in the traditional pharmacological system, it is widely used in the pharmaceutical and pharmaceutical industries to make various formulations. The quality and efficacy of a plant depends on rhoifolin (apigenin-7-o-neoesperidoside), a biologically active compound used as a chemical marker, and rhoifolin, which has a high environmental impact [15].

This study represents a critical evaluation of the latest technology in conventional practices in U. picta, phytochemistry, pharmacology, and toxicology. The article aims to propose new research strategies to use the therapeutic potential of herbal products to treat human diseases.

\section{MATERIALS AND METHODS}

The available information about the traditional uses, phytochemicals, and pharmacological properties of U. picta was searched through Web of Science, Google Scholar, PubMed, Science Direct, and Springer search using English as the retrieval languages. The keywords used include U. picta, Prishnaparni, traditional uses, phytochemistry, bioactive components, pharmacological activities, toxicology, and other related words. All references were from experimental studies and published before September 2020 was reviewed.

Available information on traditional uses, phytochemicals, and pharmacological properties of U. picta was analyzed by Web of Science, Google Scholar, PubMed, Science Direct, and Springer using English as the search language. The keywords used are U. picta, Prishnaparni, traditional use, phytochemistry, bioactive substances, pharmacological activities, toxicology, and other related words. All references to experimental research were published and published in September 2020 .

\section{BOTANICAL ASPECTS}

\section{Morphology}

U. picta is a straight tree between 1 and $2.5 \mathrm{~m}$ tall. At the bottom are wooden stems. The leaves are composed of 2-5 leaflets and pinnate pairs. In the vegetation phase, the pairs of leaves appear without the final 
leaves. The lower leaves are oval, $2-8 \mathrm{~cm}$ long and 2-3 $\mathrm{cm}$ wide; the upper leaves are 7-25 cm, 5-25 mm wide, and oval-lanceolate. The number of inflorescence flowers is between 35 and 75 (it is $10-70 \mathrm{~cm}$ long on a stem $0-5 \mathrm{~cm}$ long), usually in dense clusters like thorns that are pink or purple $1.5 \mathrm{~m}$ long. There are long clusters and terminals. The bracts are the highest at the base and top. The fruits are between 2 and 6 seeds and the parts are almost separated. The fruits are hairless, distinctive, and gray. The seeds are light brown, tall, and about $2.5 \times 1.5 \mathrm{~mm}$ (Fig. 1).

- Plant growth habit: Annual woody erect

- Soil: Loam to clay loam

- Plant size: 1-2.5 m height

- Leaf: 1.4-7.2 × 0.6-3 cm, elliptic-oblong

- Flowering season: July to September

- Flower: Bright reddish purple

- Fruit shape and size: 0.4-1.2 cm long

- Fruit color: Gray

- Seed: Light brown, oblong, $2.5 \times 1.5 \mathrm{~mm}$

- Fruit season: December to January $[23,24]$

Taxonomical classification:

- Kingdom: Plantae

- Subkingdom: Viridiplantae

- Superorder: Rosanae

- Order: Fabales

- Class: Magnoliopsida

- Subclass: Rosidae

- Family: Leguminosae

- Sub-family: Fabaceae

- Genus: Uraria

- Species: Picta - (Jacq) DC [25,26].

Vernacular names:

- Sanskrit: Citraparni, Kalasi, Dhavani, Prishniparni, Galvanina

- Hindi: Pithava, Dabra

- Marathi: Pithava, Prishniparni

- Tamil: Oppai

- Telugu: Murele Honne, Andale home, Prushniparni

- Gujarati: Pithava

- Bengali: Salpani, Chhalani, Chakule

- Kannada: Kolakuponna

- Malayalam: Oril

- Panjabi: Detedarnee

- Oriya: Prushnipamee, Shankar Jata [27].

\section{TRADITIONAL USES}

U. picta is prescribed for boiling cough, chills, and fever. The antiseptic leaves are well thought out and used to get gonorrhea. The roots and pods are used to treat infantile rectal prolapse. The capsules are used to treat oral pain in children. It is used to treat urinary tract diseases, tumors, and inflammation, smoking and breathing problems. Its paste mixed with water is used as a remedy for snake bites. It is the Ayurvedic medicine of the Indian system of medicine for the treatment of general fatigue. It is an antioxidant, analgesic, and anti-inflammatory drug in medicine [28,29]. The herb is traditionally used as an antipyretic, diuretic, astringent (used for irritable bowel syndrome, diarrhea, and dysentery) against colds, diuretics, anthelmintics, laxatives, and tonic nerves. As in China, where U. picta is used as a popular remedy, it is mainly used to treat fever, neutralize toxins, relieve pain, stimulate blood circulation, relieve cough, and improve breathing [30].

Charaka and Sushruta prescribed the entire plant, internally in prescriptions, in misperistalsis, diarrhea, dysentery, cough, consumption, respiratory diseases, abdominal glands, and fever from the inside of the whole herb; relieve asthma attacks as an ingredient in a drink to increase breast milk. Charaka gave him liquid porridge cooked with Prishnparni for the bloody bottom; it is cooked with Prishnparni, processed with dry rice and bullet (Sida cordifolia) for bleeding piles and hemorrhage. Sushruta places boiled milk on the ground with Prishnparni, added with sugar and honey, for gout; powdered root of Prishnparni with meat soup for promoting adhesion of fractured bone [17].

\section{PHYTOCHEMISTRY}

The plant is said to contain alkaloids, flavonoids, steroids, terpenoids, phenols, and saponins, all of which are components of plants. The tannins were not in the stem and roots, and the glycosides in the internal organs were in the roots [26]. Various significant compounds secluded from the root bark of $U$. picta are 5,7-dihydroxy-2'-methoxy3',4'-methylenedioxyisoflavanone and 4',5-dihydroxy-2',3'-dimethoxy7-(5-hydroxyoxychromen-7yl)-isoflavanone [18], stigmasta-4, 22-diene-3-one, ß-Sitosterol, and lupeol. Recently, a flavonoid rhoifolin (Apigenin-7-o-neohesperidoside) has been isolated from this plant [10].

\section{PHARMACOLOGY}

\section{Anti-inflammatory}

Singh, 2017, showed significant activity against both inflammatory models. Extraction of methanol from the U. picta roots reduced the inflammation of the treated egg albumin and formalin in a dosedependent manner [23]. Naik and Krishnamurthy, in 2018, performed anti-inflammatory activities against the whole plant against leg edema caused by carrageenan of $U$. picta methanol extract in albino rats. Methanol extracted from U. picta was extracted at weight doses of 200$400 \mathrm{mg} / \mathrm{kg}$. The measure of inhibition of the extracts was compared with a standard reference drug indomethacin. This study provides information on pharmacological evidence showing that $U$. picta can be used as an anti-inflammatory agent [31]. Regarding anti-inflammatory activity, Olufemi et al., in 2016, the $U$. picta leaf ethanol initiative significantly inhibited edema depending on the inflammation caused by carrageenan and the formation of granuloma caused by Cotton pinch in mice. It has anti-inflammatory activities due to stabilization of the lysosomal membrane of COX-2 [32,33].

\section{Hepatoprotective effects}

Singh, in 2017, tested liver damage caused by PCM $2000 \mathrm{mg} / \mathrm{kg}$ in mice to increase blood levels of the enzyme alanine transaminase (ALT), alkaline phosphatase (ALP), and aspartate aminotransferase (AST) in mice. Administration of methanol extract from $U$. picta roots reduced ALT, ALP, and AST enzyme levels, equivalent to the standard drug silymarin $[23,34,35]$.

\section{Anti-acaricidal activity}

Igboechi et al. examined the acaricidal activity of extracts of $U$. picta in 1989. In total methanol extraction has been found to be 21 times more effective than acaricide than water extract. This aspect of efficacy clearly shows that the acaricidal principles of $U$. picta are better removed from water with alcoholic solvents $[19,36]$

\section{Antimicrobial efficacy}

Osazuwa and Igboechi, in 1988, carried out antimicrobial activity of two chemicals isolated from $U$. picta leaves. Isolation had significant static or bactericidal and fungistatic or fungicidal activity. These effects have been demonstrated in numerous microorganisms. The results of the study provide scientific support for the timely application of $U$. picta leaves to treat skin diseases and to accelerate the healing of fractures $[18,37,38]$.

\section{Antinociceptive effect}

In terms of antinociceptive effect, Amole et al., 2016, show a marked inhibition of acetic acid-induced bending, resulting in a shortened UP duck period in the duck test formally induced in mice. The ethanol leaf extract has an contraceptive effect, induced by opioid mechanisms, ATP-sensitive $\mathrm{K}+$ channels, and nitric oxide $[39,40]$.

\section{Antioxidant activity}

Patel et al., 2011, approaches the free radical elimination potential of $U$. picta ethanol extract. Several in vitro models have been studied for their radical elimination properties, namely, DPPH radical scavenger 
test, ABTS radical scavenger test, 0-phenanthroline test, lipid peroxidation test, superoxide capture test, non-enzymatic hemoglobin glycosylation test, and total antioxidant. The total antioxidant capacity of the ethanol extract from U. picta $(10 \mathrm{mg} / \mathrm{ml})$ corresponds to 63.31 $\mathrm{mg} / \mathrm{ml}$ ascorbic acid. It showed $84.89 \%$ inhibition in the nonenzymatic hemoglobin glycosylation test. In summary, significant antioxidant activity has been associated with the presence of phenol derivatives, flavonoids, sterols, and terpenes [41]. Mohan et al., 2019, determined the free radical elimination activity from the leaves, stems, and roots of U. picta. Antioxidant activity was determined using the DPPH method to eliminate free radicals. It was found that ethanolic extracts and aqueous root extract from leaves and stems contain the lowest $\mathrm{IC}_{50}$ and hence the highest antioxidant activity. Based on the results, it can be concluded that the most promising antioxidant activity was demonstrated due to the presence of various extracts from the leaves, stems, and roots of U. picta, ethanolic extracts from leaves and stems, and aqueous extracts from the roots of phenols and flavonoid compounds $[26,42,43]$.

\section{In the treatment of Alzheimer's disease}

Odubanjo et al., 2013, investigated the in vitro connection of an aqueous extract of $U$. picta with acetylcholinesterase and butyrylcholinesterase enzymes with Alzheimer's disease. In vitro inhibition, total phenol content and radical scavenging ability of acetylcholinesterase and butyrylcholinesterase were evaluated. The enzyme acetylcholinesterase and butyrylcholinesterase inhibited by the extract in a dose-dependent manner. The extract contains phenols and flavonoids. The extract also removed the 2,2-azino-bis (3-ethylbenzthiazoline-6-sulfonic acid) (ABTS) residue and hydroxyl (OH) residue in a dose-dependent manner. The inhibition of acetylcholinesterase, butyrylcholinesterase, and the antioxidant properties demonstrated could make $U$. picta extract a good agent for the treatment/control of Alzheimer's disease [44-47].

\section{Fracture healing activity}

Prasad et al., 1965, studied the healing of fractures with radioactive P-32 and Ca-45 under the influence of $U$. picta. Albino rats, in 130 groups, received $45 \mathrm{Ca}$ or $32 \mathrm{P}$ injections $24 \mathrm{~h}$ before death; half of these groups were injected twice a week with U. picta alcohol extract and half with distilled water. Seven rats per group were killed at 5 weeks/week. They all had a broken arm bone. Bone radioactivity was measured and a bone was used for autoradiography. Bone activity is described in terms of the relationship between the humerus with the rupture of radioactivity and the whole humerus. When used as a $32 \mathrm{P}$ indicator, bone radioactivity was higher in the $2^{\text {nd }}$ and $3^{\text {rd }}$ weeks compared to untreated rats in urea-extracted rats; Animals treated with $46 \mathrm{Ca}$ showed the highest radioactivity at week 4 , significantly better than the untreated group [48-50].

\section{Cancer activity}

In 2013, Eldahshan studied rhoifolin as an antitumor activity that is almost comparable to vinblastine, tested against human cell laryngeal occult carcinoma (Hep 2) and human cervical carcinoma (HeLa) cell lines. Promising activities have also been achieved against hepatocellular carcinoma (Hep G2), large intestine (HCT-116), and human fetal lung fibroblasts (MRC-5). A special effect of rhoifolin was the absence of cytotoxic activity against normal healthy cells (Vero cells), indicating the high selectivity of this compound [40,51]

\section{Protective effect}

Kale et al., in 2012, overuse of NSAIDs (anti-inflammatory steroids) resulted in nephrotoxicity, such as paracetamol, liver necrosis, and renal failure, occurring inapproximately $1-2 \%$ of patients with acetaminophen overdose. Treatment with $U$. picta gold extract containing polyphenolic compounds and carbohydrates can significantly reduce urine urea and BUN levels, increase serum creatinine levels and urine creatinine with the paracetamol group. The stimulating activity of the summary may be due to its ability to activate antioxidant enzymes. The results suggest that it may be used as a new therapeutic agent that is not suitable for adapting the water extract of $U$. picta $[14,52-55]$.
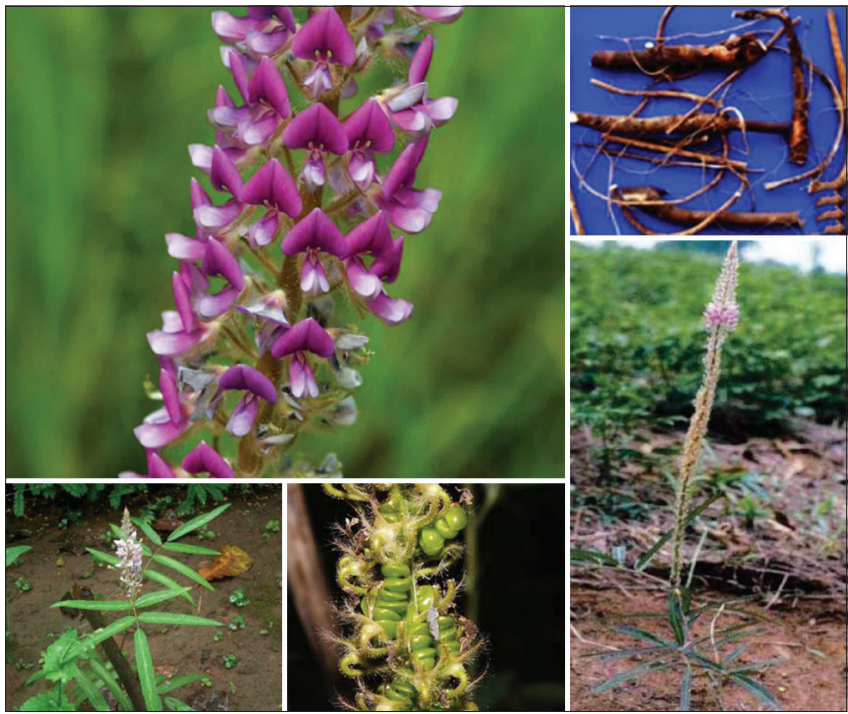

Fig. 1: Whole plant, leaves, flower, and fruits of Uraria picta

\section{Antidiabetic activity}

Fatokun et al., 2012, studied the activity of oral glucose tolerance of U. picta (leaves) in a model animal fed on a high-calorie diet to induce Type II diabetes. Sprague-Dawley 120 male rats were divided into two main groups. One group received a normal rat diet and the other group a high-calorie diet for 4 months. Raw herbal extracts were made by boiling, pressing, drying, and heating using traditional methods of sweetening. The untreated group and the rat group treated with metformin were used as controls and comparators, respectively. Each animal received different doses of oral herbal extracts at 3 weeks. Blood was taken from all rats before the analysis of glucose concentration. During this period, the animals were weighed weekly and fed every 3 days. After the dosing period, an oral glucose tolerance test was performed and blood samples were taken empty on the stomach for 0 , 30, 60, and $120 \mathrm{~min}$, and glucose concentrations were analyzed. U. picta showed a marked difference in the effect of reducing plasma glucose in rats fed a normal diet. The effects of plant extracts on weight and food intake were very small and were not significant in most groups. Doses of $U$. picta usually given to animals in the diet have greatly improved glucose clearance [56-60].

\section{Anxiolytic activity}

Garg, 2015, provided several types of summaries of $U$. picta leaves to rats at a dose of $200 \mathrm{mg} / \mathrm{kg}, 400 \mathrm{mg} / \mathrm{kg}$, and $600 \mathrm{mg} / \mathrm{kg}$ with a thin pharmacological CNS. Anxiety-like activities have plant antioxidant effects and may be due to their ability to cleanse free radicals. The study compared diazepam, the standard anti-anxiety medication [61-65].

\section{TOXICOLOGY}

Acute oral toxicity studies did not show mortality in mice up to $5 \mathrm{~g} / \mathrm{kg}$, but the i.p. administered UP produced LD of $812.83 \mathrm{mg} / \mathrm{kg}$; in addition, oral dose administration of 50 and $500 \mathrm{mg} / \mathrm{kg}$ resulted in a significant dose reduction $(\mathrm{p}<0.05)$ in the number of line crossings and dosedependent culture behavior $(\mathrm{p}<0.05)$. The results of this study show that ethanol leaf extract from U. picta is oral [32].

\section{CONCLUSION AND FUTURE OF THE AUDIT}

$U$. picta is an excellent medicinal plant with traditional bioactive ingredients, such as antidiabetic, antitumor, anxiolytic, antioxidant, antinociceptive, antimicrobial, anti arizid agents and Arthritis. Pharmacological studies on crude compounds and extracts have demonstrated extensive biological effects of $U$. picta and provided basic evidence for its common use. While the overview is that $U$. picta provides a comprehensive summary of information on botanical, conventional, 
and ethnographic functions, phytochemistry, pharmacology, and toxicity, there are still some gaps that require scientific evaluation and research.

Initially, many studies were focused on controlling conventional pharmacological activities, phyto-chemical analysis of the extract was poorly evaluated, and functional components were unknown. Some studies did not mention methods of identification and detailed information about the U. Picta (such as location, date of harvest, development phase, plant or plant parts, and harvesters). Second, some new results were evaluated, which had some problems with pharmacological methods and experimental designs. Some of the methods used in the pharmacological activities of $U$. picta have not been developed because there is no positive control group, which makes the results less reliable. Third, data on many aspects of $U$. picta, such as acute and chronic toxicity, pharmacokinetics, quality control standards, and the clinical value of medications are limited, so more needs to be done. Study to determine safety and toxicological limits and provides instructions for clinical applications.

In summary, knowledge of $U$. picta in traditional uses, its origins, chemical components, pharmacological activities, and toxicology has shown that $U$. picta is more popular and supports further research into the development of new herbal and health products.

\section{ACKNOWLEDGMENT}

I am thankful to Dr. D. Y. Patil Institute of Pharmaceutical Sciences and Research, Pimpri, Pune, India, for providing all the necessary facilities and support to carry out this study.

\section{AUTHORS' CONTRIBUTIONS}

Mr. Jaykumar Mane contribution included designing and preparing the review paper. Dr. Dheeraj Nagore and Dr. Sohan Chitlange contribution included data checking. All the authors have read the final manuscript and approved the submission.

\section{CONFLICTS OF INTEREST}

The authors declare no conflicts of interest.

\section{AUTHORS' FUNDING}

None.

\section{REFERENCES}

1. Sastri BN. The wealth of India. A dictionary of Indian raw materials and industrial products. Raw Mater 1962;6:21-30.

2. Hooker JD. The flora of British India. In: The Flora of British India. Vol. 1. Australia: Reeve; 1872.

3. Kirtikar KR, Basu BD. Indian Medicinal Plants. Allahabad: Lalit Mohan Publication; 1935.

4. Yusuf M, Chowdhury JU, Wahab MA, Begum J. Medical Plants of Bangladesh. Dhaka: BCSIR Chittagong Laboratory; 1994. p. 73.

5. McNeill J. International code of botanical nomenclature. In: Seventeenth International Botanical Congress Vienna. Vol. 568. Austria: International Atomic Energy Agency; 2005.

6. Ohashi H, Iokawa Y. A revision of Uraria (Leguminosae) in Taiwan. Taiwania 2007;52:177-83.

7. Billore KV, Yelne MB, Dennis TJ, Chaudhari BG. Database on Medicinal Plants Used in Ayurveda. Vol. 6. New Delhi: Central Council for Research in Ayurveda and Siddha; 2004. p. 314-20.

8. Yadav AK, Yadav D, Shanker K, Verma RK, Saxena AK, Gupta MM. Flavone glycoside based validated RP-LC method for quality evaluation of Prishniparni (Uraria picta). Chromatographia 2009;69:653-8.

9. Pathak JM, Krishnamurthy R, Chandorkar MS, Gulkari VD. Gupta $\mathrm{R}$ identification of high yielding genotypes of Dashmool Shalparni (Desmodium gangeticum) drug plant and its cultivation under high density planting. Indian J Hortic 2005;62:378-84.

10. Saxena HO, Soni A, Mohammad N, Kakkar A, Singh N. HPLC analysis of rhoifolin in different plant parts of Uraria picta: A dashmool species. Indian J Trop Biodivers 2014;22:199-201.
11. Government of India. The Ayurvedic Formulary of India, Part I. India: Government of India; 2003. p. 55.

12. Sastry K. Caraka Samhita of Agnivesa with Cakrapanidatta Tika. Varanasi: Chaukhambha Sanskrit Sansthan; 1997.

13. Bhattacharya A, Datta AK. A report on genetic male sterility in Uraria picta (Jacq.) DC. Cytologia 2011;76:55-62.

14. Kale RH, Halde UK, Biyani KR. Protective effect of aqueous extract of Uraria picta on acetaminophen induced nephrotoxicity in rats. Int J Res Pharm Biomed Sci 2012;3:110-3.

15. Saxena HO, Mohan B, Kakkar A. Assessment of variation in Rhoifolin content in aerial parts of Uraria picta Desv. from different locations of Madhya Pradesh. J Pharm Res 2016;10:185-90.

16. Gurav AM, Dhanorkar VM, Dhar BP, Lavekar GS. In vitro propagation of the medicinal plant Uraria picta (Jacq.) Desv. ex DC. from cotyledonary node and nodal explants. Pharmacogn Mag 2008;4:S239-45

17. Khare CP. Indian Medicinal Plants: An Illustrated Dictionary. Berlin: Springer; 2007. p. 699-700.

18. Rahman MM, Gibbons S, Gray AI. Isoflavanones from Uraria picta and their antimicrobial activity. Phytochemistry 2007;68:1692-7.

19. Igboechi AC, Osazuwa EO, Igwe UE. Laboratory evaluation of the acaricidal properties of extracts from Uraria picta (Leguminosae). J Ethnopharmacol 1989;26:293-8.

20. Manonmani S, Vishwanathan VP, Subramanian S, Govindasamy S. Biochemical studies on the antiulcerogenic activity of cauvery 100 , an ayurvedic formulation in experimental ulcers. Indian J Pharmacol 1995;27:101.

21. Occhiuto F, Limardi F. Comparative effects of the flavonoids luteolin, apiin and rhoifolin on experimental pulmonary hypertension in the dog. Phytother Res 1994;8:153-6.

22. Occhiuto F, Circosta C, de Pasquale A, Briguglio F. Comparative haemodynamic effects of the flavonoids rhoifolin and vitexin in the dog. Phytother Res 1990;4:118-20.

23. Singh NK. Anti-inflammatory and hepatoprotective activities of the roots of Uraria picta. Int J Green Pharm 2017;11:S116-73.

24. Rastogi C, Paswan SK, Verma P, Vishwakarma V, Srivastava S, Rao CV. Chapter-6 Uraria picta: A comprehensive review and its pharmacological action. Recent Adv Pharm Sci 2011;76:93.

25. Groom A. Uraria picta, in IUCN Red List of Threatened Species. International Union for Conservation of Nature and Natural Resources, IUCN; 2012.

26. Saxena HO, Soni A, Mohammad N, Choubey SK. Phytochemical screening and elemental analysis in different plant parts of Uraria picta Desv.: A dashmul species. J Chem Pharm Res 2014;6:756-60.

27. Committee AP. The Ayurvedic Pharmacopoeia of India, Part-I. New Delhi, India: Government of India, Ministry of Health and Family Welfare, Department of Ayurveda, Yoga \& Naturopathy, Unani, Siddha and Homoeopathy (AYUSH); 2004.

28. Parrotta JA. Healing Plants of Peninsular India. United Kingdom: CABI Publishing; 2001

29. Ved DK, Goraya GS. Demand and supply of medicinal plants in India. Bangalore, New Delhi, India: FRLHT, NMPB; 2007. p. 18

30. Xueqin M, Chengjian Z, Changling H, Khalid R, Luping Q. The genus desmodium (fabaceae)-traditional uses in Chinese medicine, phytochemistry and pharmacology. J Ethnopharmacol 2011;138: 314-32.

31. Naik K, Krishnamurthy R. Anti-inflammatory activity of methanolic extracts of Pseudarthria viscida and Uraria picta against carrageenan induced paw edema in albino rat. J Med Aromat Plants 2018;9:1.

32. Olufemi AO, Omoniyi YK, Akinyinka AA, Ibitayo AM. Mechanistic evaluation of toxicity, antinociceptive, antiinflammatory and antioxidant actions of leaf extract of Uraria picta. LASU J Med Sci 2016:1:1-10

33. Ghildiyal S, Gautam MK, Joshi VK, Goel RK. Anti-inflammatory activity of two classical formulations of laghupanchamula in rats. $\mathrm{J}$ Ayurveda Integr Med 2013;4:23-7.

34. Arka G, Anindita K, Ankit S, Kumar SA, Kumar MS. Preliminary evaluation of hepatoprotective potential of the polyherbal formulation. J Intercult Ethnopharmacol 2015;4:118-24.

35. Kumar B, Prasad P, Mehdi J, Gupta A, Shanker K, Singh M, et al. Morpho-metric and molecular characterization of Uraria picta (Jacq.) Desv. ex DC.-a medicinal plant. J Appl Res Med Aromat Plants 2020;1:100242.

36. Srilakshmi US, Raj GA. Standardizationo of dashamoola kwatha choorna: A herbal compound drug used for parisheka in spastic cerebral palsy. Int J Pharm Sci Res 2018;9:4937-40.

37. Osazuwa EO, Igboechi AC. Anti-microbial activity of a chemical 
isolate from the leaves of Uraria picta. Phytother Res 1988;2:204-6

38. Laxman AM, Goga GS, Dayaram NT. Seed viability and influence of presowing treatments on germination and seedling development of Uraria picta (Jacq.) DC. Seed Sci Biotech 2009;3:48-53.

39. Amole OO, Mofomosara SH, Ekene OA. Evaluation of the antidiarrhoeal effect of Lannea welwitschii Hiern (Anacardiaceae) bark extract. Afr J Pharm Pharmacol 2010;4:151-7.

40. Agrawal K. Review of drugs under laghupanchmula. J Pharmacogn Phytochem 2018:7:3363-9.

41. Patel BD, Kamariya YH, Patel MB. Free radical scavenging potential of ethanolic extract of Uraria picta Linn. Pharmacologyonline 2011;2:134-45.

42. Mohan B, Saxena HO, Kakkar A, Mishra MK. Determination of antioxidant activity, total phenolic and flavonoid contents in leaves, stem and roots of Uraria picta Desv. Environ Conserv J 2019;20:1-8.

43. Patel BD, Kamariya YH, Patel MB. Antioxidant potential of aqueous extract of entire plant of Uraria picta Desv. J Int Pharm Res 2011:3:92-6.

44. Odubanjo VO, Oboh G, Ibukun EO. Antioxidant and anticholinesterase activities of aqueous extract of Uraria picta (Jacq.) DC. Afr J Pharm Pharmacol 2013;7:2768-73.

45. Bansal N, Parle M. Beneficial effect of chyawanprash on cognitive function in aged mice. Pharm Biol 2011;49:2-8

46. Sonibare MA, Ayoola IO, Elufioye TO. Antioxidant and acetylcholinesterase inhibitory activities of leaf extract and fractions of Albizia adianthifolia (Schumach) WF Wright. J Basic Clin Physiol Pharmacol 2017;28:143-8.

47. Alias NZ, Idris MH, Somat NA, Mahmud N, Hasan S, Wai LK, et al. Synthesis, antioxidant, anticholinesterase activities and molecular docking studies of coumaryl 1, 3-selenazoles derivatives. Preprints 2020;1:1-10

48. Prasad GU, Sankaran PS, Pande PJ. Studies on fracture healing by using radioactive $\mathrm{P}-32$ and $\mathrm{Ca}-45$ under the influence of Uraria picta. Indian J Med Res 1965;53:645-50.

49. Singla C, Drabu S, Verma R, Dhiman A, Sharma A. Recent update on proficient bone fracture revivifying herbs. Int Res J Pharm 2011;2:3-5.

50. Singh V. Medicinal plants and bone healing. Natl J Maxillofac Surg 2017:8:4-11.

51. Eldahshan OA. Rhoifolin; a potent antiproliferative effect on cancer cell lines. J Pharm Res Int 2013;3:46-53.
52. Al-Doaiss AA. Hepatotoxicity-induced by the therapeutic dose of acetaminophenand the ameliorative effect of oral co-administration of selenium/Tribulus terrestris extract in rats. Int J Morphol 2020;38:1444-54.

53. Hemlal H, Ravi S. GC-MS, HPTLC and antimicrobial analysis of root extracts of Pseudarthria viscida Wight and Arn and Desmodium gangeticum (Linn.) DC. Int Res J Biol Sci 2012;1:57-65.

54. Gaiuson WY, Solomon NE, Yaduma N, Samaila IM, Thagriki D. Preliminary evaluation of hepatorenal protective potentials of Kigelia africana Ethanolic leaf extract on carbon tetrachloride induced toxicity in adult male wistar rats. Am $\backslash \mathrm{J}$ Plant Sci 2020;11:1345.

55. Sivakrishnan S, Kottaimuthu A. Hepatoprotective activity of ethanolic extract of aerial parts of Albizia procera Roxb (Benth.) against paracetamol induced liver toxicity on wistar rats. Int J Pharm Pharm Sci 2014;6:233-8.

56. Fatokun FK, Danckwerts MP, Crowther N. Oral glucose tolerance of traditional medicines in a diabetes induced rat model. Int J Pharmacogn Phytochem Res 2012;4:41-8.

57. Ramaiah M, Amani P, Bhavitha S, Gayathri T, Lohitha T. A pharmacological and phytochemical based review on Uraria lagopodoides (L.) DC. J Integral Sci 2019;1:1-5.

58. Jayaprasad B, Thamayandhi D, Sharavanan PS. Traditionally using antidiabetic medicinal plants in Tamil Nadu. Int J Res Pharm Biosci 2012;2:1-8.

59. Gopalakrishnan G, Dhanapal CK. Evaluation of anti-diabetic activity of methanolic extract of Coleus vettiveroides Jacob in streptozotocininduced diabetic rats. J Pharm Sci Res 2014;6:97.

60. Joshi PR, Patel BR. Pratinidhi dravya and its adaptation in current scenario-a birds eye view. Res Pharm 2012;1:1-5.

61. Garg N. Phytochemical studies and anti anxiey activity of Uraria Picta leaves. J Res Opin 2015;2:1-5

62. Sarris J, McIntyre E, Camfield DA. Plant-based medicines for anxiety disorders, Part 1. CNS Drugs 2013;27:207-19.

63. De Sousa A. Herbal medicines and anxiety disorders: An overview. J Med Plants 2013;1:18-23.

64. Roy-Byrne PP, Bystritsky A, Russo J, Craske MG, Sherbourne CD, Stein MB. Use of herbal medicine in primary care patients with mood and anxiety disorders. Psychosomatics 2005;46:117-22.

65. Ernst E. Herbal remedies for anxiety-a systematic review of controlled clinical trials. Phytomedicine 2006;13:205-8. 